\title{
Restating the Case: How Revisiting the Development of the Case Method Can Help Us Think Differently About the Future of the Business School
}

\author{
TODD BRIDGMAN \\ STEPHEN CUMMINGS \\ Victoria University of Wellington, New Zealand \\ COLM MCLAUGHLIN \\ University College Dublin, Dublin, Ireland
}

\begin{abstract}
Although supportive of calls for business schools to learn the lessons of history to address contemporary challenges about their legitimacy and impact, we argue that our ability to learn is limited by the histories we have created. Through contrasting the contested development of the case method of teaching at Harvard Business School and the conventional history of its rise, we argue that this history, which promotes a smooth linear evolution, works against reconceptualizing the role of the business school. To illustrate this, we develop a "counterhistory" of the case method-one that reveals a contested and circuitous path of development-and discuss how recognizing this would encourage us to think differently. This counterhistory provides a means of stimulating debate and innovative thinking about how business schools can address their legitimacy challenges, and, in doing so, have a more positive impact on society.
\end{abstract}

"How can we state the aims of the school?... giving the student training for practice in dealing with business problems. This requires practice in (1) Ascertaining focts; (2) approising and sorting facts; (3) stating business problems in a business way; (4) analyzing business problems; (5) reaching definite conclusions; (6) presenting such conclusions orally and in writing" (Memorandum from Dean Donham outlining his vision for HBS in 1920, in Copeland, 1958: 77).

"Cases portray high-stakes battles in which individuals face difficult and consequential

We are grateful to the staff of the Baker Library Historical Collections at Harvard Business School, especially Katherine Fox for giving us permission to publish the archival data, as well as Horvard University Archives for assisting us during our visits. business decisions. . Proper judgment matters, since mistaken decisions in a warlike environment can have disastrous outcomes" (Anteby, 2013: 82).

Harvard Business School (HBS) may be the single most influential institution in the history of business education. A common explanation for this is HBS' unwavering clarity of purpose: that the principal objective of a business education is to learn how to solve business problems through the case method of teaching (often referred to as the Harvard Case Method).

Reinforcing this notion is clarity about what the case method is, a consensus that has been passed down through the years in a way that is indicative of it always having been so. The case method "asks not 
how a man may be trained to know, but how a man may be trained to act" (Dewing, 1931: 2). Students take real-life situations and "learn how to determine what the real problem is and to ask the right questions" (Hommond, 1976: 2). Through on analytical process, a set of recommendations are developed for solving the problem. The magic of the case method is not so much that there is a right answer (Delves Broughton, 2008) - it is not about students looking in the back of the book to see if they have arrived at the right solution (Gragg, 1940) - it is that there must be an answer, arrived at by the careful weighing up of the facts of the case (Copeland, 1958).

Anteby (2013) provides us with a valuable insight into the "inner workings" (p. 140) of contemporary case method practice at HBS in Manufacturing Morals, an ethnographic account of how faculty and students are socialized to focus on solving cases in a businesslike manner, subsequently avoiding the discussion or promotion of value and moral positions. Case teaching is highly choreographed, a "well-oiled collective apparatus," Anteby explains (2013: 53), with teaching notes providing intricate details of which questions to ask when, and what whiteboards should look like at the end of teaching sessions. Although faculty are free, in theory, to teach as they wish, this is discouraged by organizational routines. In particular, "preaching-of specific conclusions or any moral viewpoint-is seen as an ineffective mode of instruction. If anything, preaching in silence is the norm at the School" (2013: 69).

In recent years, following corporate scandals and the global financial crisis, some have criticized this method. Attention has focused on the shortcomings of today's business graduates, with the HBS case approach seen as contributing to a norrow, instrumental, amoral, managerial perspective on business. It has been criticized for constructing mythical, heroic portrayals of leadership (Chetkovich \& Kirp, 2001; Collinson \& Tourish, 2015); privileging senior management views (Mintzberg, 2004); and managerialism (Contardo \& Wensley, 2004); encouraging narrow, functionalist understandings of business, rather than holistic thinking (Podolny, 2009); leading students toward predetermined answers (Currie \& Tempest, 2008); focusing on the solving of problems rather than the framing and definition of problems (Chia, 2005); excluding the voice of women, the poor (Kweder, 2014); and labor (Starkey \& Tiratsoo, 2007); neglecting the interests and influence of other stakeholders (Bridgman, 2010; Starkey \& Tempest, 2009); and containing a flawed logic of translatability from one context to others (Grey, 2004). Its pervasive influence on business education globally is also seen as a concern: For example, Liang and Wang (2004) warn Chinese case writers against "blindly following the case writing approach of the Harvard Business School" (p. 4l1) because HBS cases treat organizations as "a mere tool for profits, while neglecting their social nature" (p. 404). At the heart of these criticisms of the case method is its emphasis on action and application, the way it locates students in the position of leaders/managers, requiring them to diagnose situations and prescribe solutions.

And yet, despite these criticisms, and despite the flux and transformation that has characterized many other areas of business education, the belief in the case method has endured and grown in strength. For Harvard faculty such as David Garvin and other case method "evangelists" (Garvin, 2003: 56), its raison d'être, the emphasis on action and business application, is the cause of its longevity and success. The case method is still a key part of the HBS ethos, an ethos that many (if not most) business schools seek to mimic. It seems that nearly 100 years of history is hard to shift. Like it, criticize it, or defend it against those criticisms, it is what it is. Except that it isn't.

\section{"And yet, despite these criticisms, and despite the flux and transformation which that has characterized many other areas of business education, the belief in the case method has endured and grown in strength."}

The emergence of the case method is not a solid straight line from Dean Donham's conception in his 1920 memorandum (cited at the head of this article), through Dewing and Hammond, to Anteby's statement 95 years later. In the 1920s and 30s, in response to social and economic crises, Donham and several of his contemporaries began to rethink what the case method, and by association, business schools, could be. But this contrary view has been glossed over in histories of management, business schools, and the case method itself.

Our aim here is to contribute a deeper understanding of history to the burgeoning literature on the institutional development of business schools (e.g., 
Pettigrew, Cornuel, \& Hommel, 2004; Thomas, Lorange, \& Sheth, 2013), and in particular to considerations of their legitimacy and impact. ${ }^{1}$ Within this aim are two objectives: First, using the case method as our illustrative case, we examine past challenges to the legitimacy of business schools and their responses, to inform discussions about contemporary challenges. As Starkey (2015, 661-662) notes, "if those who fail to learn from history are condemned to repeat it, then we need to focus much more seriously on history." There is, we believe, more than a passing resemblance between the turbulent macroeconomic environment of the Great Depression era and today's questioning of the future of capitalism and relations between government and society (Henisz, 2011; Marens, 2010; Mills, Weatherbee, Foster, \& Helms Mills, 2015).

Our second objective is to think more deeply about the relationship between history and legitimacy. In responding to Starkey's call to take "history" seriously, we make a distinction between history and the "past." We see the past as events that have occurred already, and history as being a narrative of past events: the connection we have to the past, which we can draw on to make sense of both it, the present, and the future. To explore the role played by histories in shaping our view of the Harvard case method and the shape of business schools in general, we draw on the concept of invented tradition:

A set of practices, normally governed by overtly or tacitly accepted rules and of a ritual or symbolic nature, which seeks to inculcate certain values and norms of behaviour by repetition, which automatically implies continuity with the past (Hobsbawm \& Ranger, 1983:1).

According to this view, traditions that are claimed are often not what they appear, being constructions of a "suitable historic past" (1983: 1). Rowlinson and Hassard (1993), for example, show the significance

\footnotetext{
${ }^{1}$ We define legitimacy as "a generalized perception or assumption that the actions of an entity are desirable, proper, or appropriate within some socially constructed system of norms, values, beliefs, and definitions" (Suchman, 1995: 574). In this sense, legitimacy is critical to the survival of an organization (Ashforth \& Gibbs, 1990), with high-legitimacy institutions better able to attract funding and high-quality staff, more likely to be seen as trustworthy, enjoying better support from society and having greater influence and impact (Deephouse \& Suchman, 2008; Dowling \& Pfeffer, 1975).
}

of the Cadbury family's Quaker beliefs to be a retrospective construction by the confectionary company and those who produced its histories. Such invented traditions have the effect of establishing inculcating beliefs and values, establishing social cohesion and authority relations, thereby providing legitimacy. They also shape present and future practice by developing conventions, which become established as "best practice" that is passed onto new practitioners.

Below, we present the "invented tradition" of the case method at HBS, the conventional history agreed upon by both its defenders and critics. Then, in the second part of the article, we construct a "counterhistory" that highlights events and characters from the past that have been forgotten or ignored by the conventional history. This counterhistory is inspired by Michel Foucault's (1977a; 1985) critical and alternative histories written to counter the way conventional historical understandings bound present thinking. Foucault (1977a: 143ff.) regarded such histories as legitimating the establishment and closing down alternatives: What is recorded as the "origin [becomes] the site of truth" and in a circular manner "makes possible a field of knowledge whose function is to recover it." Such origins tend to be picked out and promoted because they relate to present concerns. "In placing present needs at the origin," Foucault (1977a: 148) continued, conventional histories "convince us of an obscure purpose that seeks its realization at the moment it arises," and, over time, this "truth" then becomes "the sort of error that cannot be refuted because it [has been] hardened into an unalterable form in the long baking process of history" (1977a: 144).

Foucault consequently defined the purpose of a counterhistory in this way: "Instead of legitimating what is already known [it aims to rethink historical assumptions in order to] free thought from what it silently thinks, and so enable it to think differently" (Foucault, 1985: 9). Foucault did not aim for or claim to uncover the whole truth, but to raise doubts about what was promoted as the truth of an evolution (e.g., Foucault, 1977b). Drawing on Foucault's approach, we believe that our counterhistory of the case method's past can help us think differently about what the case method could be, as well as inform discussions about the legitimacy and impact of business schools in new and interesting ways. We conclude with some observations about the paradoxical nature of business school legitimacy and the role played by histories in this regard. 


\section{THE CONVENTIONAL HISTORY OF THE HBS CASE METHOD}

\section{Clarity of Purpose, Refinement, Evolution}

Most histories of the HBS case method follow a narrow channel-starting with the business school's adaptation of the approach to legal education at Harvard (Copeland, 1958; Garvin, 2003; Grandon Gill, 2011; Merseth, 1991; Mesny, 2013). In 1870 Christopher Columbus Langdell, dean of the Harvard Law School (HLS), felt law would be best studied through the derivation of general principles from numerous examples, so he took the radical step of refusing to give a lecture, instead asking a surprised student to "state the case" (Cruikshank, 1987: 74). An interested observer of the law school's experiment was Edwin Gay, dean of Harvard's business school, which was established in 1908. Despite Gay's enthusiasm for the "problem method" as he called it, uptake was slow, because unlike in law, there was no corpus of cases available to work with, and the school lacked the financial resources needed to employ researchers to produce them (Copelond, 1958). Following Gay's decision to resign his deanship in 1919, Harvard President Lawrence Lowell, formerly a professor in the Department of Government, approached his former protégé, Wallace Donham, to replace him. Lowell had funded Donham through HLS, such was the promise he saw in him. Upon graduating, Donham worked in banking, specializing in corporate restructuring and achieving some notoriety as a court-appointed receiver for the troubled Bay State Street Railway Company between 1917 and 1919. The electric street railway sector was rationalizing in the face of increased competition (from the private motor car) and higher labor and materials costs. Donham kept several thousand streetcar workers on the job throughout the war, with the railway union giving him a silver clock in recognition of his efforts (Cruikshank, 1987).

Donham accepted Lowell's offer of the deanship. He was excited by the opportunity to strengthen the business school and was keen to establish himself as an authority in the fledgling field of labor relations. Donham was familiar with the case-based approach of HLS and moved quickly to secure its future at HBS. He convinced marketing professor Melvin Copeland to produce a "problem" book rather than a standard textbook (Copeland, 1958; Cruikshank, 1987). At his first faculty meeting in 1919, Donham outlined a plan to expand the Bureau of Business Research, which would be tasked with producing "cases" (he preferred this term over "problems") for use in the classroom. After discussions with President Lowell and members of faculty, Donham prepared his memorandum, which outlined his vision for the school and the role to be played by the case method in fulfilling that vision.

Conventional accounts of the history of the case method at HBS draw a straight line from this articulation of the case method in 1920 to today. This history is presented as being important, since "modern cases retain the same basic features described by Donham" (Garvin, 2003: 60), but unremarkable, without hint of controversy.

\section{A COUNTERHISTORY OF THE HBS CASE METHOD}

\section{Breadth of Perspective, Contestation, Revolution}

\begin{abstract}
"We are not ex cathedra laying down the law about business and the way it must be done...We are not endeavoring to prevent them from thinking and to keep them from having a basis on which to think for themselves... We are trying to give them the basis for sane thought and independent thought and we are stimulating this thought as much as possible" (Dean Donham to Howard Elliott, April 27, 1921, Baker Library Historical Collections, boldface added).
\end{abstract}

As we started researching the origins of the case method in greater depth, we became aware of a much more diverse and contested past. What is understood to be the case method today is what Donham articulated in his 1920 memorandum, but missing from the conventional history is the story of how his thinking, and those of others at Harvard, was challenged as the United States became gripped by social and economic crisis-conditions not dissimilar, it could be argued, to the present. Our interest in past responses by business schools to challenges to their legitimacy, and the parallels between the 1920s and 30s to today, led us to focus on the interwar period at HBS, under Donham's deanship. Our empirical work began with an analysis of existing histories of the case method, which we used to construct the conventional history presented above. Our archival work was centered on the HBS Archives in the school's Baker Library, which contain records from its founding in 1908, including collections for the first seven deans, up to Kim Clork who served from 1995 to 2005. We did a comprehensive search of the Donham collection using the finding aid, which details the organization and contents of the collection and comprises one volume called "HBS Dean's 
Correspondence 1919-1942" and four volumes called "School Correspondence." We were particularly interested in correspondence that dealt with the case method and with issues concerning the legitimacy of the institution. With regard to the latter, having identified Donham's relationship with English philosopher Alfred North Whitehead as significant, we visited the Harvard University Archives to search their papers for Whitehead. There are also extensive online resources, which we searched for material relevant to the objectives of the article, in particular Harvard Business Review, HBS Bulletin, and Harvard Crimson (the daily newspaper of Harvard College) for the period 1925-1945.

Our approach for analyzing the data were consistent with the philosophical assumptions we hold regarding the relationship between history and the past. Our purpose was to construct a counterhistory to the conventional history. In presenting these narratives of the past, we neither refute the conventional history nor claim a superior objectivity for our counterhistory, for these positions would be incompatible with our view that all histories are necessarily subjective; that is, written from a perspective that reflects the concerns of the writer.

In our counterhistory of the development of the case method, we focus on a series of "critical moments" during Donham's deanship that shed new light on the past and have the potential to stimulate new thinking on the challenges facing business schools today. These events coalesce around Donham's relationships with Robert Fechner and Ordway Tead-two men typically absent in histories of the HBS case method-and with Whitehead, whose contribution is selectively appropriated by those histories.

\section{FECHNER AND DONHAM}

\section{A Broader Perspective to Understand Organized Labor}

As noted earlier, historical accounts of the HBS case method view the cultivation of a managerial mindset as an integral and enduring feature, with students required to slip into "the shoes of the managers" (Hammond, 2009: 1). Yet, an incident early in Donhom's tenure as dean, at a time when the case method was taking shape, suggests that taking the position of organized labor was part of the promise Donham saw for it. And he was prepared to stand up to those who challenged him.

The sharp deflationary recession of 1919-1920 provoked widespread industrial unrest. On the HBS program were first-year courses in Industrial Management, Labor Technique, and a second-year course in Labor Problems. The written form that we associate with the case method today had not established itself at HBS at this time; rather, courses could include a series of "walking cases" (Cruikshank, 1987: 71), with local people connected with business invited in to present their "problems" to the class. Donham himself would teach, presenting cases from his experience of the railways. Others included Tead, who would speak about his experience in conducting labor audits, and local industrialist F. C. Hood, who operated a rubber factory in Watertown, Massachusetts (Donham to Hood, 10 February 1921, Baker Library Historical Collections). Donham had learned from his time at the Bay State Street Railway Company the importance of understanding the views of unions, so he hired Robert Fechner, an influential labor leader with the International Association of American Machinists, a union affiliated to the American Federation of Labor.

Fechner's appointment raised the ire of F. C. Hood, who wrote to Donham in January 1921 with his concerns about the teaching of labor and its potential negative effect on the endowment fund. Hood noted that "some of the boys in the Business School told me that they were saturated with the union labor standpoint" (Hood to Donham, 28 January 1921, Baker Library Historical Collections). Hood also relayed his concerns to Howard Elliott, a Harvard graduate, chief executive, and endowment seeker for HBS. Elliott wrote to Donham in April 1921 questioning whether it was "a wise thing" to have Fechner lecturing "young men of impressionable age" and "sowing the seeds of social unrest" (Elliott to Donham, April 21, 1921, Baker Library Historical Collections). Donham rejected the accusation, describing Fechner's appointment as "exceedingly constructive," since labor issues had been ignored previously and providing this perspective encouraged students to think critically:

We are not ex cathedra laying down the law about business and the way it must be done; we are not trying to put these men in leading strings and control their opinions; we are not endeavoring to prevent them from thinking and to keep them from having a basis on which to think for themselves. On the contrary, everything that we are doing is intended to have exactly the opposite effect. We are trying to give them the basis for sane thought and independent thought and we are stimulating this thought as much as 
possible (Donham to Elliott, April 27, 1921, Baker

Library Historical Collections).

Howard Elliott was not reassured by Donham's letter, pointing to the "great deal of talk about the alleged radicalism and socialism of the atmosphere at Harvard" (Elliott to Donham, April 30, 1921, Baker Library Historical Collections). Correspondence between Donham and Hood continued throughout 1922 and 1923. In December of 1923, Hood wrote to Donham inquiring whether Fechner taught using cases and, if so, requesting to see them (Hood to Donham, 21 December 1923, Baker Library Historical Collections). Donham replied that "from my standpoint Fechner himself is a very definite application of the case system" (Donham to Hood, 4 January 1924, Baker Library Historical Collections). Hood penned an angry response:

The thought of any department of Harvard having professors who are socialists or Bolshevists or labor unionists is abhorrent to me, especially in these days when some of the very foundations of our Government are being attacked. . . I do not agree that Fechnor (sic) is a "definite application of the case system," or how an instructor can be a "case" (Hood to Donham, 11 January 1924, Baker Library Historical Collections).

The Fechner incident is mentioned in Cruikshank's history of HBS, but is missing from other accounts. Donham's openness to the voice of unions, based on his experiences of the railways and the rapidly shifting context of the day, is not part of the conventional history of the origins of the HBS case method. It challenges the story of a single-minded and enduring cultivation of a managerial worldview, showing the potential for cases to teach us how to think, and not merely how to act.

\section{TEAD AND DONHAM}

\section{Contesting the Values Underpinning "Rational" Managerial Actions}

The conventional account of the HBS case method's emergence gives primacy to the cultivation of judgment through discussion of real-life business problems. Donham's 1920 memorandum (reproduced earlier) outlining the case method is the epitome of a rational decision-making process: Identify the problem (or problems), analyze the causes, and take action to resolve them. Case method advocates see this as a strength, while critics highlight its failure to acknowledge the value-laden nature of managerial decision making. As Grey (2004: 180) notes,

Values are inscribed, but rarely acknowledged, in any and every management or accounting technique. For in acting upon other people and on the world, management has consequences, both good and bad, and so managers, regardless of whether they like it, and realize it, are in the domain of values.

Although the case method, with its emphasis on action and its blindness to values, is seen as anathema to a critical management education, when it was forming at HBS, contesting the values underpinning managerial actions was actually seen as part of its promise. A central character in this thread is Tead who, as noted earlier, taught with Donham and Fechner on the courses in Labor Technique and Labor Problems at HBS during the 1920s, in addition to lecturing at Columbia University. In a 1921 article on graduate training in personnel administration Tead was excited by the possibilities for the case method developing at HBS, describing it as "an exceedingly provocative method of instruction" (1921: 363) for requiring students' minds to be active, critical, and creative. This overcame the limitation of the lecture method, which merely required students to absorb the ideas of others.

Like Grey above, Tead (1960, 1964) regarded management and administration as moral arenas because of the consequences of decisions and actions taken, meaning any study of business and administration without an explicit consideration of values was an impoverished one. Faculty should reflect on their stance on moral issues that arose in their subjects, and should actively consider the wider political, economic, and cultural significance of their material. Tead also recognized the divergence of interests among different stakeholders and campaigned for democratization of the workplace through regulation to create tripartite management structures that would dilute employer power and give workers and consumers an effective voice (Nyland \& McLeod, 2007).

The stock market crash of 1929 provided fertile ground for Tead and other advocates of industrial democracy, such as Mary Parker Follett. Wage cuts, increased working hours, work intensification, threats of dismissal, and other exploitative labor 
practices had become widespread, with unemployment reaching 25\% (Kaufman, 2004). Trade union membership had plummeted though the 1920s and early 1930s, reducing the voice and bargaining power of workers. Franklin Roosevelt's New Deal legitimized collective bargaining through the National Labor Relations Act and led to an exponential growth in union membership. This institutional support for trade unions was seen by many as playing an important social and economic role in improving labor conditions and raising wages, and in turn, increasing aggregate demand and jump-starting the economy (Kaufman, 2004; O'Connor, 2001).

Tead saw great promise for the case method in helping students think deeply and critically about this rapidly transforming context. Like many of his contemporaries, he saw value in the application of psychology to industrial issues; however, he also knew that when armed with this knowledge of human behavior, "exploitation of corporate groups by clever leaders" was a real possibility (1933: 4). In the second edition of his book, Human Nature and Management, Tead added an appendix of questions and case problems. The objective was the "stimulation of clear thinking and cultivation of a broad, liberal, and humane attitude of attack on problems of human relations" (1933:309). In one case, he described a billings-department manager who started posting on the number of billings achieved by workers each week. Output increased sharply, but there had been no study by management to determine a reasonable level of output. One question assigned to the case was "How can the danger of exploitation due to the use of techniques suggested by psychological knowledge be minimized? What is exploitation?" (1933: 310).

Although Tead was well respected, and his writing was influential during this period, he appears as a marginal figure in contemporary management history. There has been some attempt to recover his contribution to management thought ( $\mathrm{O}^{\prime}$ Connor, 2001), but his writing on pedagogy has received scant attention. On the potential he saw for the case method to explore the relationship between values and actions, there is silence in the histories of the case method.

\footnotetext{
"Although Tead was well respected, and his writing was influential during this period, he appears as a marginal figure in contemporary management history."
}

\section{WHITEHEAD AND DONHAM}

\section{A Revolution in Academia Led by Practically Informed and Philosophically Guided Schools of Business}

The economic upheaval of the early 1930s sparked a radical rethink about the role of business schools. The Association to Advance Collegiate Schools of Business (AACSB), formed in 1916 to accredit business schools, became the forum where deans sought to articulate the social objectives of business schools, or what Khurana (2007) calls the "professionalization project." Donham was the strongest advocate and had prefigured the shift with his vocal commentary in the 1920s. Although the Depression was a difficult time for business schools, "it also stimulated an introspection that helped set the stage for a renewal of purpose" (Khurana, 2007: 183). The New Deal created opportunities for business schools to assert a more public role, such as in debates about the National Industrial Recovery Act, designed to stimulate economic recovery through government regulation, collective bargaining, and a national public works program. Donham was keen for HBS to play a leadership role, with himself and other faculty contributing to public forums where the merits of the Act were debated. It is to Donham's intervention in public discourse and, in particular, his relationship with Alfred North Whitehead, that we now turn.

Compared with Tead, much more prominence in histories of HBS is given to Whitehead, who joined Harvard's Philosophy Department in 1924 and stayed there until his retirement in 1937. In their book on the case method, Barnes, Christensen, and Hansen (1994: 5) note that HBS "owes a great deal to the intellectual gifts" of Whitehead, who had an enduring interest in education, being heavily involved in administrative activities during his tenure at University of London.

Whitehead rejected any distinction between abstract and practical knowledge, and one of the reasons for the shift to Harvard was to allow him the space to consider this nexus. He believed "education is not merely an appeal to the abstract intelligence. Purposeful activity, intellectual activity, and the immediate sense of worth-while achievement, should be conjoined in a unity of experience" (1933: 444). Whitehead imagined business schools as an exemplar for his revolutionary vision of the university, but for this combination of imagination and action to be fully realized, there needed to be 
freedom of thought, stimulated by a diversity of opinions and perspectives.

Whitehead's advocacy was useful for Donham and HBS, which was under attack from Veblen (1918), who saw no place for the business school in universities, and by Flexner (1930), who studied 15 case volumes at HBS and found "not the faintest glimmer of social, ethical, philosophic, historic or cultural interest" in them (p. 132). Whitehead's (1928) paper, "Universities and Their Function," was an address to the AACSB. When Donham asked Whitehead if the address could be reprinted in a publication celebrating the completion of a building project at HBS he initially agreed, but wrote to Donham the following day retracting his acceptance, saying he wanted to try Atlantic Monthly first:

After a night's reflection over the project, I am sure that it will impair a possible utility which I have very much at heart. The reference to the Business Schools-which is exactly the sort of illustration wanted for my argument-is really subordinate to the general purpose of "putting over" a way of conceiving the nature of university work in general (Whitehead to Donham, 7 May 1927, Baker Library Historical Collections).

Although Whitehead is celebrated in histories of HBS for providing Donham with legitimacy for the business school as well as a justification for the action-orientation of the case method, curiously absent are other, relevant aspects of both his thinking and his relationship with Donham. Like Tead, Whitehead was concerned how an obsession with "material things and of capital" (1925: 284) had become divorced from the active consideration of values, which were "politely bowed to, and then handed over to the clergy to be kept for Sundays" (p. 284). What was needed, Whitehead believed, was "to strengthen habits of concrete appreciation of the individual facts in their full interplay of emergent values" (p. 277), rather than the traditional approach of studying abstract ideas divorced of values.

Whitehead's view of the business school and the university was undoubtedly shaped by the dramatic changes within society at the time. He was dismayed by the speed with which industrialization had developed, as well as its form: mass production and the specialization of knowledge (1925). Whitehead saw successful societies as being based on routine, which created stability. This was under threat because of the rapid advancement of scientific technologies. In a lecture given to HBS, which appeared as the introduction of Donham's (1931) book, Business Adrift, and was later reprinted in his own book, Adventures of Ideas (1933), Whitehead called on business schools to develop foresight among their students, to enable them to understand and predict social change: the antithesis of shortsightedness, which Whitehead saw as symptomatic of his Age: "Such a reflective power is essentially a philosophic habit: it is the survey of society from the standpoint of generality" (xxvi-xxvii). What he advocated was not a study of business in society. but a study of society, based on a philosophic outlook, in which business plays an important part. "We must not fall into the fallacy of thinking of the business world in abstraction from the rest of the community. The business world is one main part of the very community which is the subjectmatter of our study" (xxvii). This idea of foresight extended beyond the notion of enlightened selfinterest that had become popular during the 1920s, as capitalists, such as J. D. Rockefeller, responded to rising labor unrest.

Donham and Whitehead developed a close relationship, meeting regularly on Saturday afternoons for lengthy discussions (Cruikshank, 1987). ${ }^{2}$ In the foreword to Business Adrift, Donham acknowledged the influence of Whitehead's thinking: "His essay summarizes and states, more clearly than I possibly could, the philosophical concepts on which my thinking is based" (p. viii). Donham accepted Whitehead's identification of constant change as the major threat facing Western civilization and saw the United States' descent into economic crisis as evidence that this threat was becoming reality. Donham called on business to maintain employment in the face of falling demand (something he had learned from his time in the railways) and advocated cutting working hours while leaving wages at existing levels, in the hope that undiminished purchasing power combined with additional leisure time would stimulate demand. Local newspaper The Harvard Crimson published the following: "These ideas are not new, but they have hitherto been considered radical, indeed socialistic, and it is a surprising indication of the progress of the times to hear them from the Dean of a Harvard graduate school"

\footnotetext{
${ }^{2}$ We found little in the Harvard archives, which we attribute to Whitehead's preference for conversations over correspondence (Hendley, 2002).
} 
(September 21, 1932). A review of Business Adrift in Time magazine (1931: 46) concluded that "beneath all the learning at Harvard Business School there is a philosophical undercurrent, the ingredient most recommended by Dean Donham to his countrymen."

By this time, Donham, having been drawn to Whitehead's philosophy, had reconceptualized the aims of the business school that had been articulated in his 1920 memo. That had focused on business schools training students to fit into managerial roles; however, Donham now realized business schools should aspire to greater sources of legitimacy and seek to have a more profound impact on shaping the world around them during this time of crisis:

Our present situation both here and in all the great industrial nations of the world is a major breakdown of capitalism. Can this be overcome? I believe so, but not without leadership which thinks in terms of broad social problems instead of in terms of particular companies (Donham, 1932: 207).

Donham was now aware of the limitations of the narrow approach to the case method he had promoted just years earlier. Business education had become preoccupied with solving problems in organizations. "We need in business and politics administrators who are able not only to handle their specialized problems well, but also to see things in wide relations and do their part in maintaining society's stability and equilibrium" (Donham, 1933: 420). However, despite these misgivings, and the opportunity to further develop the case method to focus more on the relationship between business and society, Donham looked to other parts of the HBS program to pursue this objective.

The 1930s at HBS were "a decade of unusual energy and intellectual excitement, despite straitened financial circumstances" (Cruikshank, 1987: 187). In 1931, Donham proposed a third year of study toward a Doctor of Commercial Science degree for selected students. The third year would be "devoted to an effort to train men with capacity for leadership in problems of the relation of business to civilization" (Donham, 1931, cited in Cruikshank, 1987: 198), reflecting both his dislike for specialization and his desire for the school to recognize its social obligations. In 1934, Donham broadened the school's agenda to include the study of government and its relationship to business. The following year, faculty member Professor Philip Cabot launched a program in which 70 business executives spent one weekend a month discussing the pressing problems facing the nation.

As the end of the 1930s approached, HBS was leading the way in a transformation of U.S. business schools which, Khurana (2007: 191) notes, aimed "to turn business schools into objective analysts and, when necessary, critics of business rather than the apologists and boosters they had been accused of being." Unfortunately for Donham, The Depression, while being the catalyst for new thinking, also affected the viability of new initiatives. His third-year proposal was repeatedly deferred and finally abandoned because of a lack of money. The transformation also lost impetus when a new threat loomed on the horizon: the growing aggression of Germany under Adolf Hitler.

In the histories of HBS and its case method, the contribution of Whitehead is noteworthy for what is left out. Barnes et al. (1994) credit Whitehead's lasting legacy of action-oriented learning, but say nothing of his ideas about consideration of values or business as a sociological study. McNair's (1954) collection of papers on the case method makes no mention of Whitehead at all.

Accounts of Donham's contribution are also partial. Copeland's (1958) institutional history of HBS devotes a whole chapter to Donham but makes no mention of his writing on the state of U.S. capitalism in the 1920s and 30s, despite Whitehead crediting Donham for helping to "avert the disaster of an American social revolution" (1942: 235). Donham's normative stance was seen, in retrospect, to be "confusing" (Cruikshank, 1987: 187), and has been largely forgotten by histories of HBS and its case method. In sum, the case method's history during the interwar period does not remember the contestation over what it could have been, which makes it difficult to rethink how it could be different today.

\section{Post WWII Developments Made It Easy to Gloss Over The Debates of the 1920s and 30s}

"There is no rationale or philosophy of business
capable of justification apart from a considered
philosophy of life. And until all the teachers in
schools of business perceive this profound and
necessary truth, the methods of instruction, in-
cluding the provocative case method, will re-
main thin and inconclusive. There has to be
a confronting and examining of the reasons 
why business functions, of the meaning of its functioning, and of its human purpose in a democratic society" (Tead, 1953: 106).

The business school environment after World War II was a very different place from that experienced by Tead, Donham, and Whitehead in the interwar period. There were continuing challenges to the legitimacy of business schools, but the challenges were of a different form. The crisis of the Great Depression had passed, capitalism was stabilized, and the demand for business schools to address pressing social issues dissipated. Business schools were now under pressure to improve their academic standing through the development of a systematic body of knowledge built on values of neutrality and detachment (Gordon \& Howell, 1959; O'Connor, 2012, Pierson, 1959), while preserving the ideal of management as a profession that had been the mission of business schools since their inception (Khurana, 2007). For Herbert Simon, the pursuit of "pure science" (1967: 6) was entirely "relevant" for a professional school committed to training future managers, prefiguring a debate that would resurface with intensity nearly 50 years later (Bennis \& O'Toole, 2005; Ghoshal, 2005; Pfeffer \& Fong, 2002).

Originally, Donham (1922) had hoped the case method would satisfy this demand for new knowledge by developing general principles through a process of inductive empiricism, but by the 1950s this was seen as a failed project. Supporters of the case method were now keen to distance it from science by emphasizing its training function, thus narrowing the understanding of what the case method was, or could be. Fritz Roethlisberger, a central figure in the growth of human relations at HBS, put it thus:

Although related, we assumed there were two kinds of knowledge that needed to be different. One is the kind of knowledge that is associated with the scientist who is seeking to make verifiable propositions about a certain class of phenomena. The other is a kind of knowledge that is associated with the practitioner of a skill in relation to a class of phenomena (Roethlisberger, 1954: 8).

The practitioner, said Roethlisberger, was like a skillful carpenter who knew what wood to use in certain situations compared with the wood scientists who understood the composition of woods. HBS decided it was better equipped to train carpenters than create wood theorists (Barnes et al., 1994). At this time, the narrow, managerialist understanding of the case method as originally conceived by Donham in his 1920 memo fitted well with the ideological underpinnings of human relations that had transformed the HBS curriculum: being democratic (students participate in class rather than being "told what to think"); individual (every situation is treated differently and stereotypes and categorizations are avoided); and cooperative (students have a common goal to analyze the case and learn from each other; Ronken, 1953). Kenneth Andrews' (1953) edited book, dedicated to Donham, The Case Method of Teaching Human Relations and Administration, contained contributions from HBS faculty involved in teaching and researching human relations. In a chapter by Harriet Ronken, "What One Student Learned," Ronken tells the story of Allen Price, a student who held left-wing views and was resistant to the case method: "He went outside the case; he told stories from his own experience; he reported newspaper articles on topics like 'unions'... he appealed to anything that he thought would give him grounds for an opinion except the case" (1953: 49-50). Over time however, he learned to engage with the complexity of the individual cases, started to consider his own psychological processes, and shifted from thinking in stereotypes about "union members" and "capitalists" to seeking to understand what Ronken calls "real people" (p. 62).

The failure to realize the promise of a critically reflexive case method was a disappointment for Tead. The quotation at the head of this section comes from Tead's review of Andrews' edited volume. Although Tead remained supportive of the case method, he was "also for far more which it curiously ignores" (Tead, 1953: 106). In his view, it had become an "educational gadget." Developments after WWII were largely technical ones, such as parabola-shaped classrooms and positioning lecturers below their students, rather than overlooking them from a raised platform, as had been the situation before (Barnes et al., 1994). For Tead, business cases had become problemsolving exercises underpinned by the unscrutinized values of profit maximization and logistic feasibility. It was a pity, he said, "that there is no longer an Alfred North Whitehead to help lead the technicians out of the bleak wilderness of techniques discussed without benefit of some philosophy" (1953: 106). 


\section{DISCUSSION}

\section{Reconstructing History to Inspire Innovation for the Future}

Histories of the case method and of HBS itself do not see the debates and complexities that we are interested in here. Rather, they construct a narrative in which the case method was only ever thought of as the mechanism for training future managers to solve narrow business problems. The case method is celebrated by those who believe this is what a business education should be about, and lamented by those-including critical management educators-who desire an education where the values underpinning managerial actions are more deeply scrutinized. The latter are skeptical of HBS' motives for giving greater attention to social responsibility in the 1930s, with Donham typically portrayed as a realist who knew that capitalism was teetering and was determined to retain managerial autonomy (O'Connor, 1999; Yogev, 2001). After all, his exemplars of enlightened self-interest were Rockefeller and Carnegie who "harmonized" their economic and social obligations (Donham, 1927), hardly a challenge to the establishment.

Our purpose here is not to dismiss the interpretations of those for or against HBS and the case method-the pursuit of legitimacy is often accompanied by accusations of self-interest masquerading as altruism (Boyle, 2004)-but to construct a counterhistory that might inspire thinking differently. The dramatically shifting context of the 1920s and 30s provided fertile ground for the germination of a range of radically different ways of thinking about business education. Donham's interactions with Fechner, Tead, and Whitehead suggest that irrespective of his initial motivations, his actions went beyond political expediency. The controversy surrounding Fechner suggests a genuine determination on Donham's part to have the voice of organized labor represented. Tead saw potential for the case method to provide a deep, critical reflection on the use and potential abuse of knowledge about management, informed by the explicit consideration of values. And Donham's friendship with Whitehead significontly shifted his thinking about business and its sociological function and led to his interventions in national political debate. It also gave him a new perspective on the limitations of the case method in its conventional form. Revisiting these events can, we believe, provide a useful spur for innovation now: about both the case method itself and the legitimacy and roles played by business schools in the 2lst century. We summarize three ways in which we believe this can happen in the paragraphs below.

\section{Scrutinizing Labor Relations Rather Than Dismissing Them As Irrelevant, Unfashionable, or Not Our Business}

In providing teaching on labor relations in the early 1920s, the express purpose was to expose students to "real-world" problems and get students to understand these "problems" from the perspective of labor, rather than examine them soley from the perspective of capital. Donham fought hard to resist the pressure exerted by F. C. Hood over his appointment of Fechner, which left him open to accusations of formenting communist beliefs among the student body. Donham rejected the accusation that including the voice of organized labor was "dangerous," highlighting the value of gaining a genuine understanding of this perspective. In addition, Tead was an advocate of increasing worker voice and workplace democracy through collective bargaining and strong trade unions.

In the current context, organized labor has been in decline over a long period. Trade unions do, however, remain an influential actor in many countries, particularly at the macrolevel in serving on tripartite committees; lobbying government on industrial relations reforms; or working with MNCs, NGOs, and international bodies on framework agreements aimed at improving working conditions in supply chains. Despite this, the rights of workers to freedom of association and collective bargaining through trade unions (Principle 3 of the United Nations Global Compact) have largely been airbrushed out of business school curriculums. Industrial Relations departments have been forced to rename themselves as Human Resource Management departments or are subsumed under the broader umbrella of organization studies. Similarly, unions rorely appear in HBS case studies (Anteby, 2013), and indeed, are largely absent among the writings of critical management scholars: They have become something of a "missing subject" within the business school (Bridgman \& McLaughlin, 2012). We might also extend the lesson of Donham's defense of the inclusion of organized labor to other stakeholders, who had less of a presence in the 1920s and 30s, and who may be impacted by management decisions and may not share the same managerial perspective, such as nonunionized workers, particularly those marginalized in atypical and insecure 
employment, local communities, and NGOs. We are not envisioning the classic "stakeholder perspective," where students consider the interests of other stakeholders and take them into account in making a decision, but rather that their perspective might be analyzed as part of a deeper and more critical thinking around the impact of business on its stakeholders and on society (Starkey \& Tempest, 2009).

\section{"Despite this, the rights of workers to freedom of association and collective bargaining through trade unions (Principle 3 of the United Nations Global Compact) have largely been airbrushed out of business school curriculums."}

\section{Stimulating Processes of Critical Reflection: Cases Are an Opportunity to Think About How We Think}

We could also strive to realize the vision Tead had for using the case method to develop the students' ability to assess critically the assumptions underpinning managerial actions and the impact of those actions on others (Cunliffe, 2004). As the case method became settled after World War II, it became wedded to the ideological positioning of human relations. Notable in Andrews' (1953) volume is that while a number of the contributors talk about the importance of challenging preconceptions and assumptions, this critical questioning is narrowly confined within the managerialist worldview of human relations as a subject. Tead had in mind a far more radical questioning, which required an in-depth understanding of the advancements in industrial psychology, coupled with an awareness of its exploitative effects, especially if applied instrumentally in organizations. It is a study "of" management rather than "for" management, an aim shared by critical management educators. These issues remain as relevant today as they were nearly a century ago, given what we know about the poor treatment of workers in MNC supply chains; the growth of zero hour contracts (which shift many of the risks in employment from the employer to the employee); exploitation of local communities; and the impacts of business on climate change.
Against the Narrowing Tendencies of "Decision Forcing:" Addressing the Global Challenges of Our Age Through Encouraging Innovative Responses to Cases

Undoubtedly there has been a surge of interest in business ethics in the wake of the financial crisis, in the hope that future business leaders might act more ethically (Currie, Knights, \& Starkey, 2010). This implies that unethical conduct is the result of morally deficient managers, rather than a product of the broader system (Bridgman, 2010). For both Tead and Whitehead, business was a part of a wider society and needed to be examined in that context, and this influenced Donham in his concern about the direction of U.S. capitalism and what he saw as an increasing fragmentation of society's fabric. Taking inspiration from his approach calls for an analysis that integrates individual managerial behavior with a range of social, political, and ideological factors.

To do this requires challenging the dominance of the decision-forcing case: the structuring technique that places students in the "shoes" of a character in the case, usually a manager, needing to make a decision to solve a business problem. Decision-forcing cases dominate because of "the conviction among teachers in the professions that the essence of professional skill is the ability to make decisions under trying circumstances" (Lynn, 1999: 107). This has the effect of socializing students into a managerial worldview by requiring them to don an ideological "hat" by making decisions based on criteria of efficiency, productivity, and profitability (Wensley, 2011).

The decision-forcing case overlooks the way in which individual managerial decisions are shaped by the structures of global capitalism, where the demands of institutional investors and the fluidity of capital markets incentivize managers to take shortterm decisions. As Thompson $(2003,2013)$ notes in his "disconnected capitalism thesis," individual managers and firms may wish to act responsibly toward their stakeholders, but they are unable to keep their side of the bargain, such is the pressure from global finance.

We would suggest that, in the spirit of Donham and Whitehead, the case method might be reenvisaged to elicit a deeper critique of modern day capitalism and its impact on society; that students be challenged with deeper questions about the relationship between business and society, such as, "do corporations have too much 
power and influence?," "what role should the state play in regulating business?," or "is contemporary capitalism part of the problem when it comes to the issues of our age, such as climate change?" (McLaughlin, 2013; McLaughlin \& Prothero, 2014). Case studies could play an important role in critically engaging students with the global challenges we face in building a more inclusive, ethical, and sustainable society: encouraging students not to think about what managers and organizations in the cases did, but how they, and other stakeholders, might have defined problems otherwise and thought and acted differently.

In advocating these three developments of the case method, we are not suggesting that the case method or HBS's approach to educating their students has remained static. Supporters of the case method have recognized that although it remains a valuable approach, management education must respond to the challenges of globalization, innovation, creativity, and technological change (Datar, Garvin, \& Cullen, 2010). There is now more attention given to experiential learning, often conducted internationally, and exposing students to business situations that are less structured and problem-focused than cases, often by way of simulations. The form of cases has evolved, with Harvard Business Publishing producing "brief cases" (5-8 pages in contrast to the traditional 30 pages); multimedia cases; and online simulations, in addition to its regular cases.

Despite these shifts, however, the case method and assumptions about its purpose remain central to the teaching of students at HBS, as well as being a key part of the HBS brand, and by association, of those other institutions that seek to be like Harvard. Harvard Business Publishing continues to produce books on the case method (Andersen \& Schiano, 2014; Ellet, 2007) and supplementary products such as online tutorials for students, as well as resources for teachers, including face-to-face seminars hosted by universities around the globe. The business of case method teaching remains as vital for HBS as ever before.

\section{Restating the Case}

"I hope that the umbilical cord that intravenously feeds the past, present and future with the sustoining power of the status quo, can be cut in order to allow for new births" (Jenkins, Refiguring History, 2003: 18).
There is a growing awareness that business education has reached a crossroads and in the aftermath of the global financial crisis, pressure for change has grown (Datar et al., 2010). Former HBS professor Joel Podolny (2009: 62) felt the "intense rage" of society and a loss of confidence in economic institutions - the business school included. Dominic Barton (2011), global managing director of McKinsey and Company, warned ominously of the potential for "the social contract between the capitalist system and the citizenry [to] truly rupture, with unpredictable but severely damaging results" (p. 86). In a tone remarkably similar to that of Donham's book, Business Adrift, Barton said business leaders face a stark choice: Either they reform capitalism, "the greatest engine of prosperity ever devised" (p. 86), or stand by and watch as government takes control.

But this initial impetus appears to be receding as institutions return to "business as usual," and there is even a backlash against those who supported change. Robert Simons (2013), who teaches the "Designing Winning Organizations" course at HBS, blames new courses on business ethics and corporate social responsibility for a decline in the competitiveness of U.S. industry. For Simons, business schools have lost focus on their only legitimate mission: "The business of business schools is teaching business. And successful businesses require an over-riding focus on the tough choices needed to prevail in competitive markets" (p. 31). Simons sees the conventional case method as salvation in this regard, because of the way it trains future managers to "make tough, consequential choices" (p. 12).

On the various sides of these debates about the negative impact and legitimacy of business schools today there is a "presentism," an assumption that today's challenges are of a scope, scale, and stake beyond anything experienced previously (e.g., Boyle, 2004; Podolny, 2009; Wilson \& Thomas, 2012). We have outlined how business schools have faced similar crises of legitimacy before-arguably at their highest intensity in the interwar period where there were not the mass enrolments that business schools enjoy today and the survival of the fledgling institution was genuinely under threat. We would be wise to take a broader historical perspective on this issue, so that we might learn from the past.

One lesson is that innovative thinking can and should be promoted in times of crisis. The default mode of business education throughout its history has been pragmatism: The "business hero, real or 
fictional, has been the "man [sic] of action" who makes courageous decisions under uncertainty to improve the bottom line (Jacques, 1996: 7). ${ }^{3}$ During times of relative stability, this pragmatism enables a focus on solving problems. However, during times of crisis, the problem-solving approach becomes a problem itself, because it is more concerned with making assumptions than with examining them. In a crisis, therefore, a "progmatic" approach to solving problems is a hindrance "while questioning basic values and assumptions-philosophy-is pragmatic" (p. 7).

Exploring this pragmatism-innovation paradox and the relationship between history and legitimacy is a second contribution here. "Invented traditions" are an important source of institutional legitimacy (Hobsbawm \& Ranger, 1983; Rowlinson \& Hassard, 1993), but legitimacy is dynamic and time-sensitive. Our analysis of the past of the HBS case method suggests that although its form was useful for Donham in 1920 to gain support from the practitioner community for the new business school, the events of the Great Depression meant this narrow actionorientation was seen as potentially undermining HBS' moral legitimacy as a responsible corporate citizen (Boyle, 2004; Suchman, 1995). This reminds us that "practices may be initially regarded as legitimate but may threaten legitimacy after they have been implemented" (Alajoutsijarvi, Juusola, \& Siltaoja, 2015: 286).

As Jenkins notes, social formations attempt to reproduce themselves in a stable condition "so that all potentially destabilizing and dangerous excesses are either absorbed or rigorously excluded" (2003: 17). Business schools' contemporary responses to questions about their legitimacy have focused on areas other than the case method. Perhaps this is because the case method, as we now know it, is considered to be at the very core of their mission, or the only approach that could ever satisfy the demands of stakeholders who see management education as legitimate because it provides a practical training in business, or the natural way to teach business. That there is now a 100 -year tradition of supposed continuity provides reassurance that we have been through tough times before and that maintaining the case method has "seen us right."

However, this may not be a good thing if we believe innovation is important. The "invented tradition" of

\footnotetext{
${ }^{3}$ Jacques in this context uses "pragmatism" to mean "being practical," rather than its technical meaning associated with the philosophical movement of pragmatism.
}

the case method has become entrenched over time, making creative thinking about the present and the future more difficult. In our time of economic, social, and environmental crises, a narrow focus on a case method designed to train students to solve business problems risks further undermining business schools' legitimacy. Despite that risk, looking again at the past can encourage us to rethink the case method and revitalize it by drawing on the debates over its form in the 1920s and 30s. Useful suggestions for this rewiring from the case method's forgotten past include adopting a broader perspective to understand organized labor, contesting the values underpinning "rational" managerial actions, and pursuing a philosophically informed, sociological study of business and society.

Although our particular focus has been a reflection on the development of the case method, it is important to note that relations between Donham, Whitehead, Tead, Hood, and Fechner were about much more than this. They were about the form of business education and its relation to society in general, and in the case of Whitehead, about the very nature of knowledge and education-issues that concern the legitimacy of business schools today. Then, and again now, business schools are under pressure to be better guardians of the public interest. Business schools want to demonstrate that they can be trusted with self-regulation, and for that they need to show that management as a profession pursues a higher aim of society's interests, rather than the narrower interest of the corporation (Khurana, 2007). Predictably, the response from business schools has been to reassure stakeholders that they can voluntarily undertake changes to regain the public's trust. HBS has again been at the forefront with initiatives such as a Hippocratic Oath for Managers, based on that undertaken by medical professionals, in which managers pledge to serve the public interest (Khurana \& Nohria, 2008), and a renewed emphasis on teaching business ethics.

For some observers, however, this has amounted to little more than "business schooling as usual" (The Economist, 2009: 82). What is required, it is argued, is for business schools to foster skepticism and act more like court jesters than cheerleaders for the corporate world. The need for this public role is illustrated by the recent scandal at Volkswagen-lauded for its commitment to corporate social responsibility at the same time as it was engaging in a sophisticated program of fraud to cheat emissions tests. As Rhodes notes (2016: 13), "the institutions central to democratic business ethics are those that 


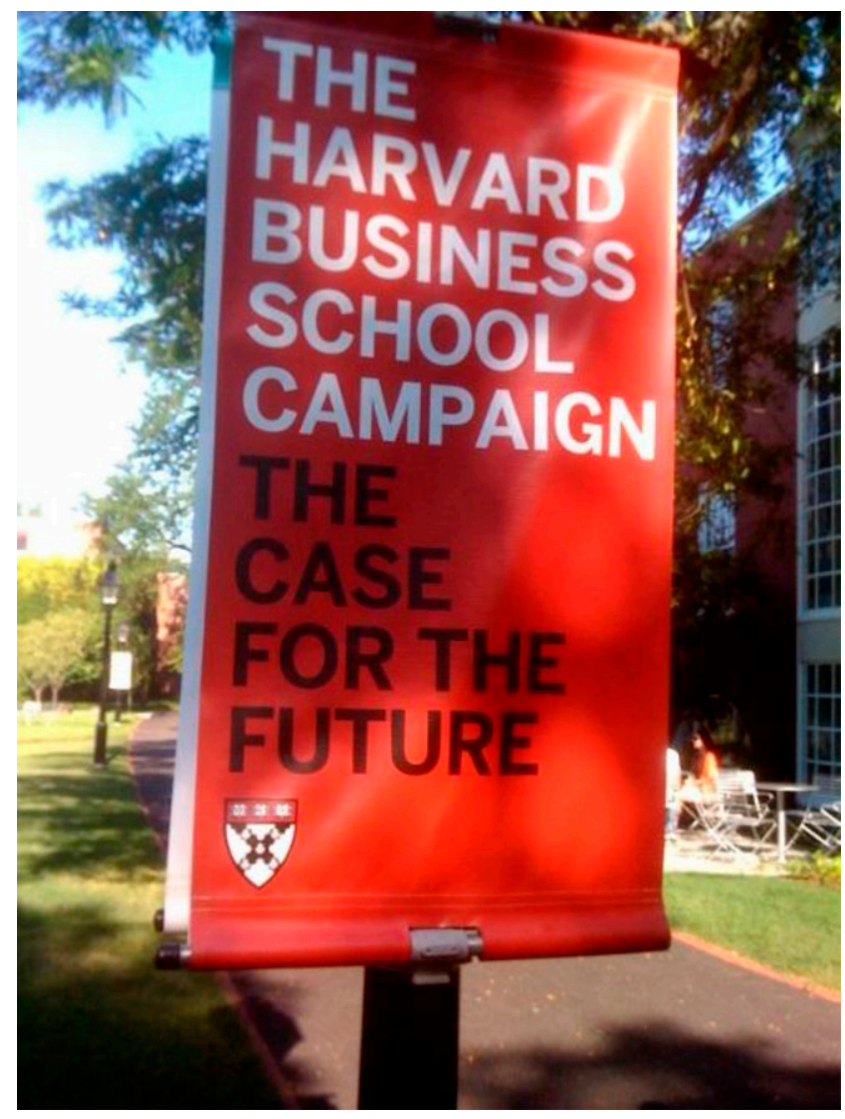

FIGURE 1

can effectively question corporations:" the media, trade unions, social movements and universities, including their business schools.

A case method which takes more seriously multiple perspectives on the business issues of the day, and a willingness of faculty to engage a wider public on these issues, is a broader conception of the "public interest model" than has been considered to date (Ferlie, McGiven, \& De Moraes, 2010). It would allow business schools to build their credibility as expert and relatively independent observers of the role of business in society, a mission articulated so well by Donham, Whitehead, and Tead.

Today, as under Donham's deanship, case teaching, pedagogy, and the mission of business schools are connected. However, today our view of one may be narrowing the others. When one looks at recent HBS advertising (see Figure 1), one likely associates it with a narrow view of conventional case teaching and either thinks the case method is great because Harvard is preeminent and has a wonderful historical lineage, or thinks it is terrible because it is an overly simplistic approach spread far and wide due to Harvard's preeminence. Our radical suggestion is that Harvard itself is not the problem stifling development; rather, it is our limited understanding of its, and our, past.

\section{"Today, as it was under Donham's deanship, case teaching, pedagogy, and the mission of business schools are connected. However, today our view of one may be narrowing the others."}

Anteby (2014) believes it is time for HBS to stop "preaching in silence" ... "when there is copious evidence that some corporate behaviors are egregiously immoral and millions of people are now facing radically reduced living conditions because of the actions of a few, silence can no longer be the answer." We share his sentiments, but not his belief that normative silence has been the way at HBS since the inception of the case method a century ago. HBS and the case method have a past that has not been a feature of their histories. Substantive innovation, of the counterhistory inspired kind we have presented here requires the "umbilical cord" of history to be cut and rerouted back through the thoughts of those who faced questions about the legitimacy of business schools in the 1920s and 30s. By rethinking and "restating the case," we can stimulate new thinking about the state of business pedagogy, education, and the aims we are seeking to serve, as managers and educators, today and for the future.

\section{REFERENCES}

Alajoutsijarvi, K., Juusola, K., \& Siltaoja, M. 2015. The legitimacy paradox of business schools: Losing by gaining? Academy of Management Learning \& Education, 14: 277-291.

Anderson, E., \& Schiano, B. 2014. Teaching with cases: A practical guide. Boston, MA: Harvard Business School Publishing.

Andrews, K. R. 1953. The case method of teaching human relations and administration. Cambridge, MA: Harvard University Press.

Anteby, M. 2013. Manufacturing morals: The values of silence and business school education. Chicago, IL: Chicago University Press.

Anteby, M. 2014. Why silence is not enough. Stanford Social Innovation Review, 22 January. Retrieved 1 June 2016 from http://ssir.org/articles/entry/why_silence_is_not_enough.

Ashforth, B. E., \& Gibbs, B. W. 1990. The double-edge of organizational legitimation. Organization Science, 1: 177-194. 
Barnes, L. B., Christensen, C. R., \& Hansen, A. J. 1994. Teaching and the case method ( $3 r d$ ed.). Boston, MA: Harvard Business School Press.

Barton, D. 2011. Capitalism for the long term. Harvard Business Review, 89(3): 84-91.

Bennis, W. G., \& O'Toole, J. 2005. How business schools lost their way. Harvard Business Review, 83(5): 96-104.

Boyle, M. 2004. Walking our talk: Business schools, legitimacy, and citizenship. Business \& Society, 43: 37-68.

Bridgman, T. 2010. Beyond the manager's moral dilemma: Rethinking the 'ideal type' business ethics case. Journal of Business Ethics, 94: 311-322.

Bridgman, T., \& McLaughlin, C. 2012. The battle for 'middle-earth': $A$ quest for national identity in an industrial dispute. Paper presented at the annual meeting of the Academy of Management, Boston.

Chetkovich, C., \& Kirp, D. L. 2001. Cases and controversies: How novitiates are trained to be masters of the public policy universe. Journal of Policy Analysis and Management, 20: 282-314.

Chia, R. 2005. The aim of management education: Reflections on Mintzberg's Managers not MBAs. Organization, 26: 1090-1092.

Collinson, D., \& Tourish, D. 2015. Teaching leadership critically: New directions for leadership pedagogy. Academy of Management Learning \& Education, 14: 576-594.

Contardo, I., \& Wensley, R. 2004. The Harvard Business School story: Avoiding knowledge by being relevant. Organization, 11: 211-231.

Copeland, M. T. 1958. And mark an era: The story of the Harvard Business School. Boston, MA: Little Brown and Company.

Cruikshank, J. L. 1987. A delicate experiment: The Harvard Business School 1908-1945. Boston, MA: Harvard Business School Press.

Cunliffe, A. 2004. On becoming a critically reflexive practitioner. Journal of Management Education, 28: 407-426.

Currie, G., Knights, D., \& Storkey, K. 2010. Introduction: A postcrisis critical reflection on business schools. British Journal of Management, 21(S1): S1-S5.

Currie, G., \& Tempest, S. 2008. Moving towards reflexive use of teaching cases. International Journal of Management Education, 7: 41-50.

Datar, S. M., Garvin, D. A., \& Cullen, P. G. 2010. Rethinking the MBA: Business education at a crossroads. Boston, MA: Harvard Business School Press.

Deephouse, D. L., \& Suchman, M. 2008. Legitimacy in organizational institutionalism. In R. Greenwood, C. Oliver, K. Shalin \& R. Suddaby (Eds.), The Sage handbook of organizational institutionalism: 49-77. London: Sage.

Delves Broughton, P. 2008. Ahead of the curve: Two years at Harvard Business School. New York: Penguin Press.

Dewing, A. S. 1931. An introduction to the use of cases. In M. P. McNair (Ed.), The case method at the Harvard Business School: 1-5. New York: McGraw-Hill.

Donham, W. B. 1921, 10 February. Letter to F. C. Hood. Box 13, Folder 13-1l. Office of the Dean (Donham) Records, (AAl.1).
Harvard Business School Archives, Baker Library, Harvard Business School.

Donham, W. B. 1921, 27 April. Letter to H. Elliott. Box 13, Folder 1311. Office of the Dean (Donham) Records, (AA1.1). Harvard Business School Archives, Baker Library, Harvard Business School.

Donham, W. B. 1922. Business teaching by the case system. The American Economic Review, 12: 53-65.

Donham, W. B. 1924, 4 January. Letter to F. C. Hood. Box 13, Folder 13-11. Office of the Dean (Donham) Records, (AA1.1). Harvard Business School Archives, Baker Library, Harvard Business School.

Donham, W. B. 1927. The social significance of business. Harvard Business Review, 5: 406-419.

Donham, W. B. 1931. Business adrift. New York: McGraw-Hill.

Donham, W. B. 1932. Business looks at the unforseen. New York: Whittlesey House/McGraw-Hill.

Donham, W. B. 1933. The failure of business leadership and the responsibilities of the universities. Harvard Business Review, 11: 418-435.

Dowling, J., \& Pfeffer, J. 1975. Organizational legitimacy: Social values and organizational behaviour. Pacific Sociological Review, 18: 122-136.

Economist, The. 2009. The pedagogy of the privileged. 26 September, 82.

Ellet, W. 2007. The case study handbook: How to read, discuss and write persuasively about cases. Boston, MA: Harvard Business School Press.

Elliott, H. 1921, 21 April. Letter to W. B. Donham. Box 10, Folder 10-31. Office of the Dean (Donham) Records, (AA1.1). Harvard Business School Archives, Baker Library, Harvard Business School.

Elliott, H. 1921, 30 April. Letter to W. B. Donham. Box 10, Folder 1031. Office of the Dean (Donham) Records, (AA1.1). Harvard Business School Archives, Baker Library, Harvard Business School.

Ferlie, E., McGivern, G., \& De Moraes, A. 2010. Developing a public interest school of management. British Journal of Management, 21: S60-S70.

Flexner, A. 1930. Universities: American, English, German. New York: Oxford University Press.

Foucault, M. 1977a. Language, counter-memory, practice. Ithaca, NY: Cornell University.

Foucault, M. 1977b. Discipline and punish: The birth of the prison. London, U.K.: Allen Lane.

Foucault, M. 1985. The history of sexuality: Volume two - The use of pleasure. New York: Pantheon.

Garvin, D. A. 2003. Making the case: Professional education for the world of practice. Harvard Magazine, 106: 56-65.

Ghoshal, S. 2005. Bad management theories are destroying good management practices. Academy of Management Learning \& Education, 4: 75-91.

Gordon, R., \& Howell, J. 1959. Higher education for business. New York: Columbia University Press.

Gragg, C. I. 1940. Because wisdom can't be told. HBS Case No. 9-451-005. Harvard Business School. 
Grandon Gill, T. 2011. Informing with the case method: A guide to case method. Santa Rosa, CA: Informing Science Press.

Grey, C. 2004. Reinventing business schools: The contribution of critical management education. Academy of Management Learning \& Education, 3: 178-186.

Hammond, J. S. 1976. Learning by the case method. HBS Case No. 9-376-241. Harvard Business School.

Hammond, J. S. 2009. Learning by the case method. Boston, MA: Harvard Business Publishing.

Harvard Crimson, The. 1932. Dean Donham's speech, September 21 .

Hendley, B. 2002. In search of the elusive Whitehead: A cautionary tole. Process Studies, 31(2): 51-63.

Henisz, W. J. 201l. Leveraging the financial crisis to fulfill the promise of progressive management. Academy of Management Learning \& Education, 10: 298-321.

Hobsbawm, E. \& Ranger, T. O. (Eds). 1983. The invention of tradition. Cambridge, U.K.: Cambridge University Press.

Hood, F. C. 1921, 28 January. Letter to W. B. Donham. Box 13, Folder 13-11. Office of the Dean (Donham) Records, (AA1.1). Harvard Business School Archives, Baker Library, Harvard Business School.

Hood, F. C. 1923, 21 December. Letter to W. B. Donham. Box 13, Folder 13-11. Office of the Dean (Donham) Records, (AA1.1). Harvard Business School Archives, Baker Library, Harvard Business School.

Hood, F. C. 1924, 11 January. Letter to W. B. Donham. Box 13, Folder 13-11. Office of the Dean (Donham) Records, (AA1.1). Harvard Business School Archives, Baker Library, Harvard Business School.

Jacques, R. 1996. Manufacturing the employee: Management knowledge from the 19th to 21 st centuries. London, U.K.: Sage.

Jenkins, K. 2003. Refiguring history: New thoughts on an old discipline. London, U.K.: Routledge.

Kaufman, B. 2004. The global evolution of industrial relations: Events, ideas and the IIRA. Geneva, Switzerland: International Labour Office.

Khurana, R. 2007. From higher aims to hired hands. Princeton, NJ: Princeton University Press.

Khurana, R., \& Nohria, N. 2008. It's time to make management a true profession. Harvard Business Review, (October): 70-77.

Kweder, M. A. 2014. Whose welfare? A critical discourse analysis of Harvard Business Publishing cases. Paper presented at the annual meeting of the Academy of Management, Philadelphia.

Liang, N., \& Wang, J. 2004. Implicit mental models in teaching cases: An empirical study of popular MBA cases in the United States and China. Academy of Management Learning \& Education, 3: 397-413.

Lynn, L. E. 1999. Teaching and learning with cases: A guidebook. New York: Seven Bridges Press.

Marens, R. 2010. Destroying the village to save it: Corporate social responsibility, labour relations, and the rise and fall of American hegemony. Organization, 17: 743-766.

McLaughlin, C. 2013. Corporate social responsibility and human resource management. In R. Carberry \& C. Cross (Eds.),
Human resource management: A concise introduction: 224-239. Basingstoke, U.K.: Palgrave Macmillan.

McLaughlin, C., \& Prothero, A. 2014. Embedding a societal view of business among first year undergraduates. In A. Murray (Ed.), Inspirational guide for the implementation of PRME: UK \& Ireland edition. Sheffield, U.K.: Greenleaf Publishing.

McNair, M. P. 1954. The case method at the Harvard Business School. New York: McGraw-Hill.

Merseth, K. K. 1991. The early history of case-based instruction: Insights for teacher education today. Journal of Teacher Education, 42: 243-249.

Mesny, A. 2013. Taking stock of the century-long utilization of the case method in management education. Canadian Journal of Administrative Sciences, 30: 56-66.

Mills, A. J., Weatherbee, T. G., Foster, J., \& Helms Mills, J. 2015. The New Deal for management and organization studies: Lessons, insights and reflections. In P. G. McLaren, A. J. Mills, \& T. G. Weatherbee (Eds.), The Routledge companion to management and organizational history: 265-284. Oxford, U.K.: Routledge.

Mintzberg, H. 2004. Managers not MBAs: A hard look at the soft practice of managing and management development. San Francisco: Barrett-Koehler.

Nyland, C., \& McLeod, A. 2007. The scientific management of the consumer interest. Business History, 49: 717-735.

O'Connor, E. 1999. The politics of management thought: A case study of the Harvard Business School and the Human Relations School. Academy of Management Review, 24: 117-131.

O'Connor, E. S. 2001. Back on the way to empowerment: The example of Ordway Tead and industrial democracy. The Journal of Applied Behavioral Science, 37: 15-32.

O'Connor, E. S. 2012. Creating new knowledge in management: Appropriating the field's lost foundations. Stanford, CA: Stanford University Press.

Pettigrew, A. M., Cornuel, E., \& Hommel, U. 2014 (Eds.). The institutional development of business schools. Oxford: Oxford University Press.

Pfeffer, J., \& Fong, C. 2002. The end of business schools? Less success than meets the eye. Academy of Management Learning \& Education, 1: 78-95.

Pierson, F. 1959. The education of American businessmen: $A$ study of university-collegiate programs in business education. New York: McGraw-Hill.

Podolny, J. M. 2009. The buck stops (and starts) at business school. Harvard Business Review, 87(6): 62-67.

Rhodes, C. 2016. Democratic business ethics: Volkswagen's emissions scandal and the disruption of corporate sovereignty. Organization Studies, 10.1177/0170840616641984.

Roethlisberger, F. J. 1954. Training for human relations. Boston, MA: Harvard Business School.

Ronken, H. O. 1953. What one student learned. In K. Andrews (Ed.), The case method of teaching human relations and administration: An interim statement: 46-65. Cambridge, MA: Harvard University Press.

Rowlinson, M., \& Hassard, J. 1993. The invention of corporate culture: A history of the histories of Cadbury. Human Relations, 46: 299-326. 
Simon, H. A. 1967. The business school a problem in organizational design. Journal of Management Studies, 4: 1-16.

Simons, R. 2013. The business of business schools: Restoring a focus on competing to win. Capitalism and Society, 8(1): Article 2.

Starkey, K. 2015. The strange absence of management during the current financial crisis. Academy of Management Review, 40: 652-663.

Starkey, K., \& Tempest, S. 2009. The winter of our discontent: The design challenge for business schools. Academy of Management Learning \& Education, 8: 576-586.

Starkey, K., \& Tiratsoo, N. 2007. The business school and the bottom line. Cambridge, U.K.: Cambridge University Press.

Suchman, M. C. 1995. Managing legitimacy: Strategic and institutional approaches. Academy of Management Review, 20: $571-610$.

Tead, O. 1921. The problem of graduate training in personnel administration. Journal of Political Economy, 29: 353-367.

Tead, O. 1933. Human nature and management, (2nd ed.). New York: McGraw-Hill.

Tead, O. 1953. Book review: The case method of teaching human relations and administration. The Personnel Journal, (July/ August): 105-106.

Tead, O. 1960. The evaluative point of view. Improving College and University Teaching, 8(1): 4-10.

Tead, O. 1964. Character and the college teacher. The Journal of Higher Education, 35: 269-272.

Thomas, H., Lorange, P., \& Sheth, J. (Eds.). 2013. The business school in the twenty-first century: Emergent challenges and new business models. Cambridge, U.K.: Cambridge University Press.

Thomas, H., \& Wilson, A. D. 2011. 'Physics envy', cognitive legitimacy or practical relevance: Dilemmas in the evolution of management research in the UK. British Journal of Management, 22: 443-456.
Thompson, P. 2003. Disconnected capitalism: Or why employers can't keep their side of the bargain. Work, Employment and Society, 17: 359-378.

Thompson, P. 2013. Financialization and the workplace: Extending and applying the disconnected capitalism thesis. Work, Employment and Society, 27: 472-488.

Time. 1931. Review of Business adrift. 17(14): 45-46.

Veblen, T. 1918. The higher learning in America: A memorandum on the conduct of universities by businessmen. New York: B. W. Huebsch.

Wensley, R. 2011. Getting too close to the fire: The challenge of engaging stories and saving lives. British Journal of Management, 22: 370-381.

Whitehead, A. N. 1925. Science and the modern world. New York: Macmillan.

Whitehead, A. N. 1927, 7 May. Letter to W. B. Donham. Box 38 , Folder 38-3. Office of the Dean (Donham) Records, (AA1.1). Harvard Business School Archives, Baker Library, Harvard Business School.

Whitehead, A. N. 1928. Universities and their function. Bulletin of the American Association of University Professors, 14: 448-450.

Whitehead, A. N. 1931. 'On foresight' in Business adrift (W. B. Donham): xi-xxix. New York: McGraw-Hill.

Whitehead, A. N. 1933. Adventures of ideas. New York: Macmillan.

Whitehead, A. N. 1942. The professionalization of business. Harvard Business School Alumni Bulletin, Summer: 235-236.

Wilson, D. C., \& Thomas, H. 2012. The legitimacy of the business of business schools: What's the future? Journal of Management Development, 31: 368-376.

Yogev, E. 2001. Corporate hand in academic glove: The new management's struggle for academic recognition - The case of the Harvard Group in the 1920s. American Studies International, 39: 52-71.

Todd Bridgman (todd.bridgman@vuw.ac.nz) is a senior lecturer in the School of Management at Victoria Business School, Wellington, New Zealand. Bridgman received his doctorate from the University of Cambridge. His research is focused on critical approaches to management learning and education, including representations of management and organizational history.

Stephen Cummings (stephen.cummings@vuw.ac.nz) is a professor of management at Victoria Business School, Wellington, New Zealand. Cummings received his doctorate from the University of Warwick. His research interests include examining how conventional historical assumptions limit innovation in management and organization studies, and creative approaches to the development and communication of strategy.

Colm McLaughlin (colm.mclaughlin@ucd.ie) is an associate professor of HRM and employment relations at UCD College of Business, University College Dublin, Ireland. McLaughlin received his doctorate from the University of Cambridge. His research focuses on the impact of institutional and regulatory frameworks on employment rights and work practices. 